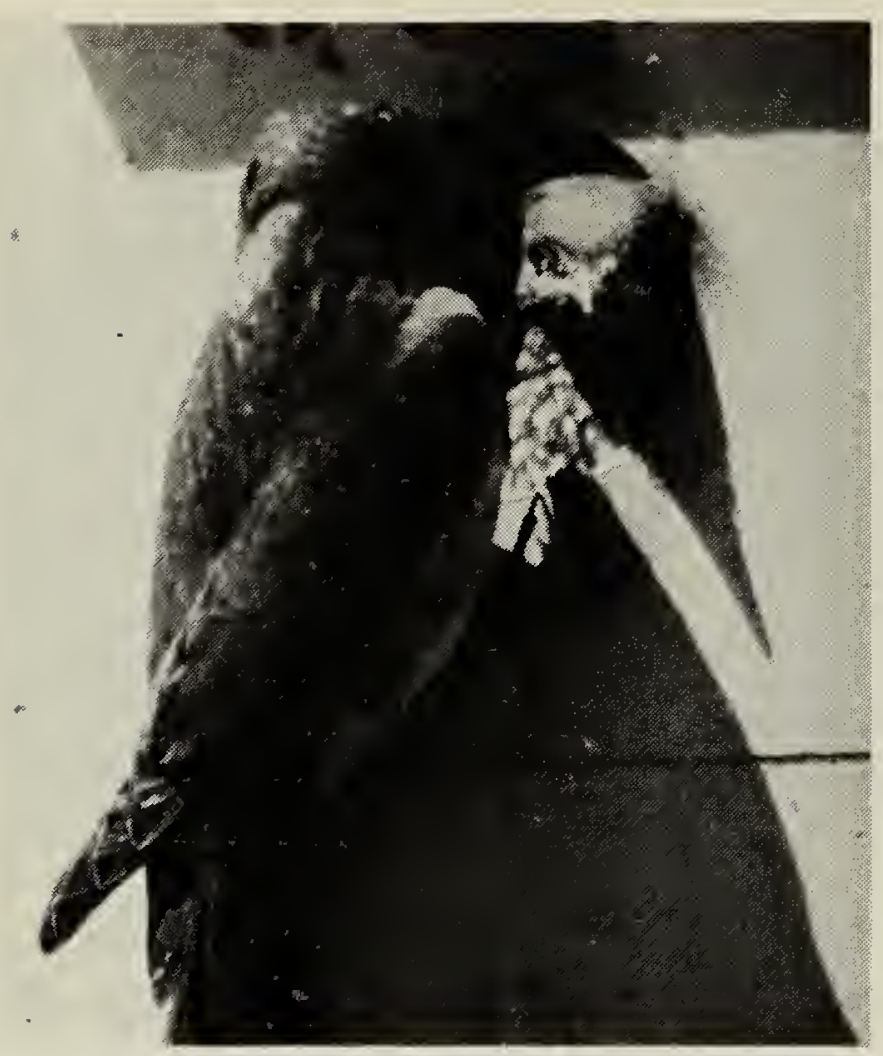

Adult Eastern Bluebird with one young at box.

John Lane

The authors wish to acknowledge with thanks the assistance of Roy Everitt, who supplied pictures, and of Mamie McCowan, who helped with preparation of the report and typed same.

"Friends of the Bluebirds" include: Austin, Manitoba: Mr. and Mrs. Wayne Brown; Mr. and Mrs. Percy Ewen. Boissevain: Charlie Reid and Malcolm Denny. Killarney: Lloyd Powell. Miami: Dale and Joan Robinson. Neepawa: Don and Mac Murray; Mrs. Sage: Mr. and Mrs. W. G. Moger. Newdale: Roy and Edie Everitt. Pratt: Mr. and Mrs. Les North. Russell: Jim and Mildred Spear; Richard Wileman, Robbie Glasman. Shoal Lake: Cliff Findlay. Souris: Art and Joyce Michie. Wawanesa: Ed and Ivy Robinson. Brandon: Mrs. John Lane; Brandon Junior Birders; Barbara Robinson; Dick and Hazel Patmore; David Randall: John and Marion Robinson; $\mathrm{Mr}$. A. L. Campbell, Lisa and Patrick; Ken James: Barbara Robertson; Phyllis Ilsley; Betty Shankland; Margaret, Helen and Mamie McCowan; the Bauman family: Dr. R. Hamilton and daughters; John and Dorothy Mayhew; also Watty Forsythe and John Plum, who kept us supplied with new nestboxes.

\section{WESTERN KINGBIRDS AND HOUSE SPARROWS}

\author{
Mrs. JOHN HUBBARD,
}

Box 453, Grenfell, Sask. SOG 2B0

I was interested in the article on the Western Kingbird killing a House Sparrow as we had an entirely opposite situation occur this summer.

Western Kingbirds frequently arrive here, build nests, fight with their neighbours and eventually leave the area, having been unsuccessful in nesting attempts. This year one was seen on June 2 nd and two more on June 3 rd and all three stayed. A pair built in a blue spruce about 20 feet high, 10 feet from our porch and 6 feet from the walk to the house; the nest was not far from the top of the tree. There was some swearing at cats and dogs, and at the third kingbird who turned up for visits and sat on a wire a short distance away. The male kingbird sat on a telephone wire about 8 feet from the nest and shared this wire with robins, sparrows, mourning doves, and, particularly, a male House Sparrow in the latter stages.

The kingbirds appeared to have their nest completed June 20th and were observed feeding young on July 18 th (the first successful nesting I know for these birds in our yard).

I have no date for their leaving the nest but I believe two young made successful exits over the heads of sleeping dogs and cats.

Four or 5 days later I was surprised to see the House Sparrows feeding young at a nest not much more than a foot beneath the kingbird's evacuated one. I knew House Sparrows had been building from the untidy mess just beneath the kingbird's nest but was surprised at their hatching so soon after the kingbirds' leaving. The female sparrow must have been pretty circumspect to have remained there while the kingbirds were feeding their young. 